\title{
Evaluation of terrestrial gastropods as possible intermediate hosts of Gurltia paralysans in southern Chile
}

\author{
Avaliação de gastrópodes terrestres como possíveis hospedeiros \\ intermediários de Gurltia paralysans no sul do Chile

\begin{abstract}
Paulina Sepúlveda-García1; Marcelo Gómez* (D); Manuel Moroni²; Pamela Muñoz²; Ananda Müller ${ }^{3,4}$
${ }^{1}$ Instituto de Farmacología y Morfofisiología, Facultad de Ciencias Veterinarias, Universidad Austral de Chile, Valdivia, Chile ${ }^{2}$ Instituto de Patología Animal, Facultad de Ciencias Veterinarias, Universidad Austral de Chile, Valdivia, Chile

${ }^{3}$ Department of Biomedical Sciences, Ross University School of Veterinary Medicine, Basseterre, Saint Kitts and Nevis
\end{abstract} \\ ${ }^{4}$ Instituto de Ciencias Clínicas Veterinarias, Facultad de Ciencias Veterinarias, Universidad Austral de Chile, Valdivia, Chile
}

How to cite: Sepúlveda-García P, Gómez M, Moroni M, Muñoz P, Müller A. Evaluation of terrestrial gastropods as possible intermediate hosts of Gurltia paralysans in southern Chile. Braz J Vet Parasito/ 2021; 30(1): e025020. https://doi.org/10.1590/S1984-296120201087

\begin{abstract}
Gurltia paralysans is the causal agent of gurltiosis in domestic cats in South America. Although the life cycle of G. paralysans is unknown, it is thought that gastropods could act as intermediate hosts (IHs), as is the case for several nematodes in the Angiostrongylidae family. The aim of this study was to search for G. paralysans larvae in terrestrial gastropods and determine their role in the life cycle of this nematode species. Terrestrial gastropod samples $(\mathrm{n}=835$ ) were collected in Punucapa, Valdivia, southern Chile, where cases of gurltiosis had been reported before. The samples included species from the families Arionidae, Limacidae, Helicidae and Milacidae. All gastropods were subjected to enzymatic digestion to isolate G. paralysans larvae. Ten percent of the gastropod samples were analyzed using seminested PCR targeting the 28S rRNA gene, while $2.6 \%$ were analyzed by histopathological examination. The results indicated the absence of $G$. paralysans when using any of the three methods. In conclusion, further studies are needed to evaluate specific species of aquatic or native gastropods acting as possible IHs (in this geographic location).
\end{abstract}

Keywords: Gurltia paralysans, Angiostrongylidae, terrestrial gastropods, intermediate host.

\section{Resumo}

Gurltia paralysans é o agente etiológico da gurltiose em gatos domésticos na América do Sul. Embora o ciclo biologico de G. paralysans seja desconhecido, provavelmente é indireto com gastrópodes atuando como hospedeiros intermediários (HIs), como no caso de vários nematoides da família Angiostrongylidae. O objetivo deste estudo foi investigar a presença de larvas de G. paralysans em gastrópodes terrestres para avaliar seu papel no ciclo de vida do parasito. Amostras de gastrópodes terrestres $(n=835)$ foram coletadas em Punucapa, Valdivia, sul do Chile, onde casos de gurltiose foram relatados anteriormente. As amostras incluíram espécies das famílias Arionidae, Limacidae, Helicidae e Milacidae. Todos os gastrópodes foram submetidos à digestão enzimática para isolar as larvas de G. paralysans. 10\% das amostras foram analisadas, utilizando-se seminested PCR para o gen 28S RNAr de G. paralysans, enquanto 2,6\% foram analisados por exame histopatológico. Os resultados indicaram ausência de G. paralysans em todos os três métodos. Os dados permitem concluir que são necessários mais estudos para avaliar espécies específicas de gastrópodes aquáticos ou nativos, que atuam como possíveis hospedeiros intermediários nessa localização geográfica.

Palavras-chave: Gurltia paralysans, Angiostrongylidae, gastrópodes terrestres, hospedeiro intermediário. 
Gurltia paralysans (superfamily Metastrongyloidea, family Angiostrongylidae) is a vascular and neurotropic nematode that parasitizes the leptomeningeal veins and spinal cord parenchyma of domestic cats, leading to meningomyelitis and chronic paraparesis/paraplegia, fecal or urinary incontinence, and/or tail paralysis (Moroni et al., 2012). Cases of feline gurltiosis have been reported in South American countries, such as Argentina, Brazil, Chile, Colombia and Uruguay (Gómez et al., 2011; Rivero et al., 2011; Moroni et al., 2012, Togni et al., 2013; Bono et al., 2016). The life cycle of $G$. paralysans is currently unknown, but it has been suggested that is indirect, as for other nematodes of the family Angiostrongylidae. It has been hypothesized that terrestrial gastropods (snails and slugs) could be intermediate hosts (IHs), and reptiles, amphibians and/or birds could participate as paratenic hosts (PHs) (Gómez et al., 2011, Moroni et al., 2012). However, the release of eggs or larval stages by the infected host has not been observed (Peña, 2014). In Chile, infected cats have been identified in rural areas in the southern part of the country, mainly from the La Araucanía, Los Ríos, and Los Lagos regions. According to previous studies in those regions, 3 out of 8 domestic cats confirmed with gurltiosis came from Punucapa city, a rural village located on the western bank of the Cruces River $20 \mathrm{~km}$ from Valdivia, Los Ríos region, Chile (Peña, 2014). The aim of this study was to evaluate whether the gastropods in Punucapa, southern Chile, are infected with the larval stages of G. paralysans and to determine whether they play a role as IIHs of this parasite.

The sampling was performed in two localities of Punucapa (39 $\left.43^{\prime} 00^{\prime \prime S}, 73^{\circ} 18^{\prime} 00^{\prime \prime W}\right)$, Valdivia, Chile, where several cases of feline gurltiosis had been previously described (Peña, 2014) (Figure 1). A total of 835 terrestrial gastropods were collected between August 2015 and November 2016. The gastropods were hand-collected between 7:30-10:00 AM, and identified by PS (author) to the species level according to South (1992). The species, place, and date of capture were recorded. The specimens were kept in plastic containers, and each gastropod was weighed, measured (width and total length) and identified, following euthanasia by immersion in water for $12 \mathrm{~h}$. Later, a sagittal section was performed on each gastropod: one-half was preserved in $10 \%$ formalin for histopathological analysis, and the remaining half was cross-sectioned into two halves, the anterior and posterior ends. The anterior section included from the cephalic region to the intestine. Posterior sections included the intestine, digestive gland, stomach, rectum, renal gonoduct and foot. One of the subset sections of the samples was stored at $-20^{\circ} \mathrm{C}$ for PCR analysis, and the remaining tissue section was subjected to enzymatic digestion.

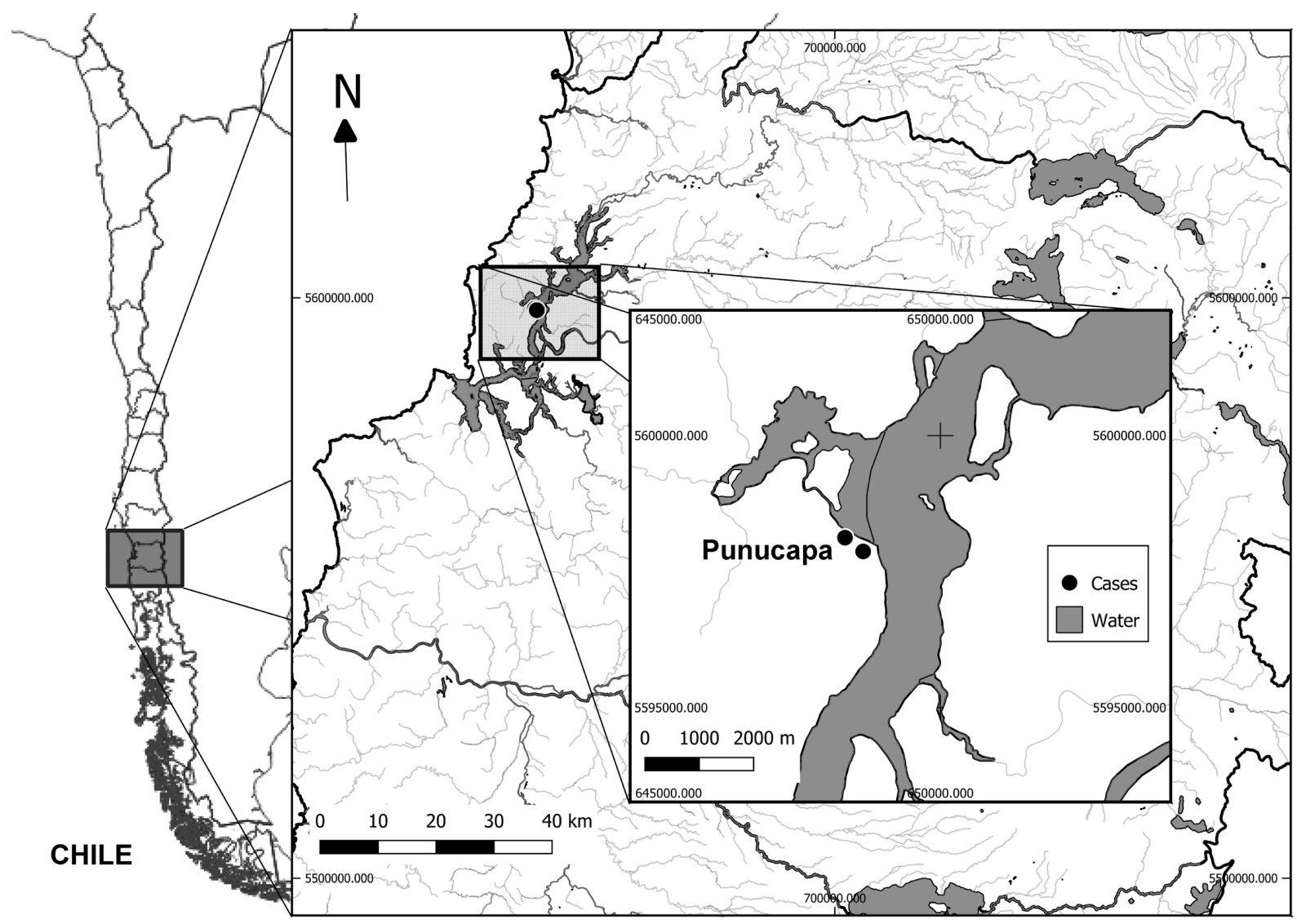

Figure 1. Location of collection points of terrestrial gastropods in Punucapa, Valdivia, southern Chile. 
The specimens were digested in pools consisting of gastropods of the same species from the same date and place of capture. First, the gastropod tissue was cut into $2 \mathrm{~mm}$ pieces and then mechanically homogenized with a pestle. In the case of snails, the carapace had been removed previously. This homogenized matter was incubated on a magnetic stirrer at $37^{\circ} \mathrm{C}$ for $2 \mathrm{~h}$ in a digestion solution with $15 \mathrm{~mL}$ of distilled water, $0.15 \mathrm{~g}$ of pepsin and $150 \mu \mathrm{L}$ of $\mathrm{HCl}$ for $1 \mathrm{~g}$ of gastropod tissue. Finally, the migration of larvae was simulated using the Baermann technique. To visualize the larvae, the sediment was transferred into a Petri dish and observed under a stereoscopic magnifying glass at 25x (Zeiss Stemi DR 1663, Germany).

A representative sample of $10 \%$ (84/835) of the gastropods previously frozen at $-20^{\circ} \mathrm{C}$ was randomly chosen for PCR analysis. DNA extraction was performed according to the manufacturer's instructions using E.Z.N.A. Mollusk DNA kit (Omega Bio-Tek, Doraville, CA, USA). The DNA samples were stored at $-20^{\circ} \mathrm{C}$. The DNA of the gastropods was amplified with the aim of ensuring the absence of pigments that inhibit DNA amplification. The Gast NLSr1 and Gast NLSf1 primers were used to amplify the 28S rRNA region of gastropods, yielding a 188-198 bp product (Table 1). The seminested PCR technique consisted of two rounds of amplification (López-Contreras et al., 2020). In the first round, the primers AaGp28Ss1 and AaGp28Sa1 were used to amplify a 444 bp of G. paralysans and 427 bp of $A$. abstrusus; those positive CPCR products were subjected to a second round of amplification using the universal primer AaGp28Ss1, and specific primers GP28Sa3 that amplified 356 bp of G. paralysans (Table 1). The reaction mixture consisted of $12.5 \mu \mathrm{L}$ GoTaqPolymerase Green Master Mix 2x (Promega, Madison, WI, USA), $0.2 \mu \mathrm{M}$ of the mentioned primers ( $0.5 \mu \mathrm{L}$ each), $10 \mu \mathrm{L}$ nuclease-free sterile water (Promega, Madison, WI, USA) and a $1.5 \mu \mathrm{L}$ DNA sample. The thermic protocol consisted of an initial step of $94^{\circ} \mathrm{C}$ for $5 \mathrm{~min}$, and $35 \mathrm{cycles}$ of: $94^{\circ} \mathrm{C}$ for $30 \mathrm{sec}, 54^{\circ} \mathrm{C}$ for $30 \mathrm{sec}$ and $72^{\circ} \mathrm{C}$ for $30 \mathrm{sec}$. The final polymerization phase occurred at $72^{\circ} \mathrm{C}$ for $5 \mathrm{~min}$. All PCRs were performed

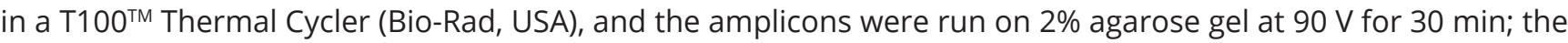
bands were visualized with UV light in a transilluminator.

Table 1. Primer sequences for amplification of the gastropod 28S rRNA region and product size in base pairs (bp) used for housekeeping and sequences of universal and specific primers used in the DNA amplification of Gurltia paralysans DNA by seminested PCR.

\begin{tabular}{cccc}
\hline Target taxon & Primer names & Primer sequences 5'-3' & Product size (bp) \\
\hline Gastropoda & GastNLSf1 & GCGGYAACGAAACGAAGT & Range 188-198 \\
& GastNLSr1 & CGAAWTMACACCGTCTCCG & x =192.7 \\
A. abstrusus & AaGp28Ss1 & CGAGTTATATGTATGCCATT & $427-444 \mathrm{pb}$ \\
G. paralysans & AaGp28Sa1 & AGGCATAGTTCACCATCT & $356 \mathrm{pb}$ \\
G. paralysans & Gp28Sa3 & TCTTGCCGCCATTATAGTAG & \\
\hline
\end{tabular}

Twenty-two samples were randomly selected for histopathology; serial sagittal cuts were obtained, fixed in $10 \%$ buffered formalin and paraffin-embedded sections, stained with hematoxylin and eosin and microscopically analyzed for histopathological evaluation.

The collected terrestrial gastropods comprised 62.2\% (519/835) Limax maximus, 19.8\% (165/835) Deroceras reticulatum, 10.7\% (89/835) Cornu aspersum, 4.2\% (35/835) Deroceras laeve, 1.3\% (11/835) Milax gagates, 1.2\% (10/835) Lehmannia valentiana, $0.6 \%$ (5/835) Arion intermedius and $0.1 \%$ (1/835) Limax flavus. A greater number of gastropods were collected during the spring of 2016, with 34.1\% (285/835), and the spring of 2015, with 21.4\% (179/835). Gurltia paralysans larvae were not isolated from the gastropod samples by enzymatic digestion. Only the presence of free-living larvae, which were characterized by the presence of a buccal opening, rhabditiform esophagus and absence of notches at the posterior end, were observed (Kuzmin et al., 2014). A total of 83 gastropod samples were analyzed by PCR, comprising 66 specimens of L. maximus, 11 of C. aspersum, 3 of D. reticulatum and 3 of M. gagates. All tissue samples were positive for endogenous gene amplification of gastropods, thus ensuring the absence of DNA amplification inhibitors. No G. paralysans DNA was identified in any of the samples during the second round of amplification; therefore, the second amplification with seminested PCR was not performed. Out of 22 gastropods randomly selected and analyzed by histopathology, 10 corresponded to the species L. maximus, 10 to C. aspersum and 2 to M. gagates. Of the gastropods analyzed, no structures similar to the larval stage of a nematode were found. However, the histological section of one of the L. maximus showed structures in the muscular fibers of the foot with characteristics that were coincident with the metacercariae of trematodes (Figure 2). 

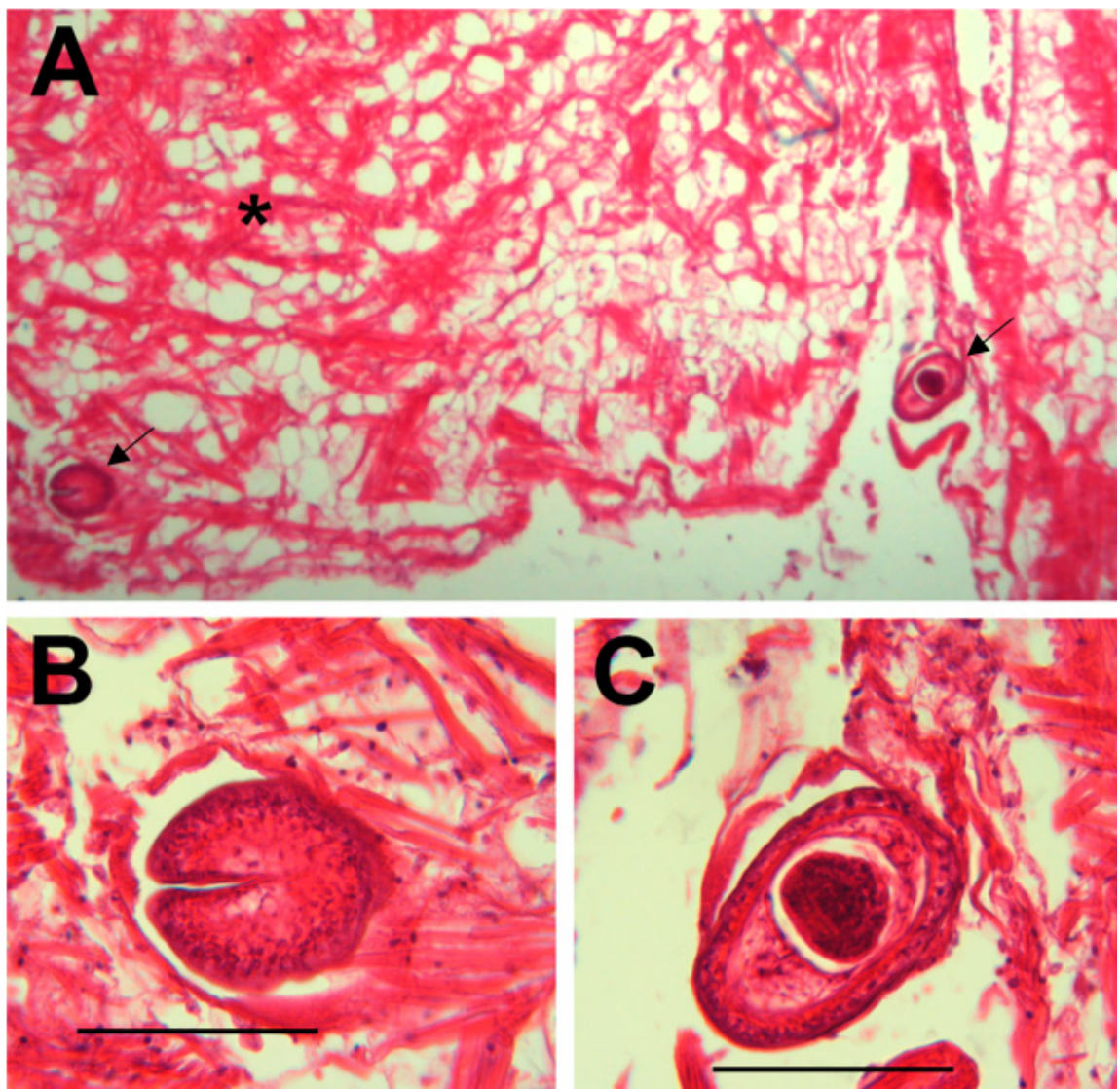

Figure 2. Figure A shows the cystic structures coinciding with metacercariae of a trematode (indicated by arrows) in the muscle fibers (indicated by an asterisk) of the foot of the Limax maximus gastropod (4X). In figures B and C, these structures are observed at higher magnification (40X). Scale bar $=50 \mu \mathrm{m}$.

Despite a history of gurltiosis in domestic cats being reported in the area of Punucapa, southern Chile (Peña, 2014), the larval stages of the nematodes of G. paralysans were not found by artificial digestion and histopathology or by DNA amplification using seminested PCR for G. paralysans. Similar results were obtained by Günther (2014) in a previous preliminary report. However, most of the analyzed gastropods in both studies have been reported previously as IHs of angiostrongylids. For instance, L. maximus is considered an $\mathrm{IH}$ of $A$. costaricensis, with an infection prevalence of $28 \%$ in Brazil (Teixeira et al., 1993), as well as of $A$. vasorum, with a prevalence of $42.9 \%$ in Denmark (Ferdushy et al., 2009). Cornu aspersum is one of the IHs of $A$. cantonensis, with a prevalence ranging from $4.5 \%$ (Chan et al., 2015) to 50\% (Martin-Alonso et al., 2015) in Australia and Spain, respectively, and it is also considered an IH of A. vasorum, with an infection prevalence of $6.7 \%$ in Scotland (Helm et al., 2015). Limax flavus is the IHs of A. costaricensis, with a prevalence of $17 \%$ in Brazil (Teixeira et al., 1993).

The negative results could be attributed to either the temporal and spatial distribution of the infection or to the collected gastropods not being the appropriate IHs. The mollusks in the present study, as in the study by Günther (2014), are invasive species in Chile and may present less capacity to act as IHs of local angiostrongylid nematode species (Morley, 2010). Gurltia paralysans has only been described in South American countries and has not been reported in Europe, which was the place of origin of the species of the collected gastropods (Rivero et al., 2011; Moroni et al., 2012). Therefore, it can be proposed that native gastropod species could be possible IHs of G. paralysans. In the present study, and in accordance to the reports of Günther (2014), no native gastropods were found, which can be explained by the presence of invading gastropod species that are apparently displacing the native species (Valdovinos et al., 2005). For instance, L. maximus, the main gastropod found in the present study, shows aggressive behavior towards other mollusks, possibly affecting the population density of native gastropods (Landler \& Nuñez, 2012). Aquatic snails could also be considered possible IHs of G. paralysans due to the close phylogenetic relationship of aquatic and terrestrial mollusks. Aquatic snails are susceptible to a wide range of terrestrial nematodes and could become more important in the biological cycle of these parasites under extreme climatic conditions, such as droughts and floods, which have negative effects on the population 
of terrestrial gastropods. High rainfall is the main factor that determines the presence of the aquatic mollusks involved in nematode transmission because the occurrence of persistent rainfall provides a suitable habitat for the development of aquatic snails as the risk of flooding increases (Morley, 2010). This climatic condition is particularly unfavorable for the population of terrestrial mollusks due to overhydration, causing mortality and, therefore, favoring the establishment of populations of aquatic gastropods (Valdovinos et al., 2005). Particularly for $A$. cantonensis, a wide variety of the aquatic snail species that act as IHs have been described, with observations of natural infection by this species in Biomphalaria alexandrina, Cleopatra bulimoides, Lanistescarinatus, Melanoides tuberculata and Pomacealineata (Ibrahim, 2007). The absence of the larval stages of angiostrongylids in the collected gastropods can also be attributed to the temporal and spatial distribution of the infection. Spatial variation in the prevalence of parasites in slugs was observed. For example, the prevalence of gastropods infected by $A$. vasorum varied within the same locality, from 0 to $26 \%$ in parks and forest areas, respectively. This situation may depend on the susceptibility, density, and behavior of the slug population, as well as on the larval population excreted by $\mathrm{DH}$ (Ferdushy et al., 2009). However, some metastrongylids do not require IHs to complete their life cycle, as in the case of Oslerusosleri, Eucoleus aerophilus and Filaaroides hirthi, so the possibility of not parasitizing an invertebrate intermediate host should also be considered for G. paralysans (Anderson, 2000).

In Chile, knowledge of the larval stages of angiostrongyloid nematodes and the gastropods that are involved in their biological cycle is scarce. Only one report, taken place in southern Chile (Günther, 2014), evaluated the participation of gastropods as possible IHs of G. paralysans, showing negative results. Therefore, further investigations are needed in this area that expand the search for species of native and aquatic gastropods.

\section{References}

Anderson RC. The superfamily Metastrongyloidea. In: Anderson RC. Nematode parasites of vertebrates their development and transmission. 2nd ed. London, UK: CABI Publishing; 2000. p. 129-172. http://dx.doi.org/10.1079/9780851994215.0000.

Bono MF, Orcellet V, Marengo R, Bosio A, Junkers E, Plaza D, et al. A description of three cases of parasitic meningomyelitis in felines from the province of Santa Fé, Argentina. Parasitaria 2016; 74(1): 1-4.

Chan D, Barratt J, Roberts T, Lee R, Shea M, Marriott D, et al. The prevalence of Angiostrongylus cantonenesis/mackerrasae complex in molluscs from the Sydney Region. PLoS One 2015; 10(5): e0128128. http://dx.doi.org/10.1371/journal.pone.0128128. PMid:26000568.

Ferdushy T, Kapel CMO, Webster P, Al-Sabi MNS, Grønvold J. The occurrence of Angiostrongylus vasorum in terrestrial slugs from forests and parks in the Copenhagen area, Denmark. J Helminthol 2009; 83(4): 379-383. http://dx.doi.org/10.1017/ S0022149X09377706. PMid:19460193.

Gómez GA, Taborda DA, Alzate A, Gutiérrez Chaparro JJ. Domestic cat paraplegia compatible with Gurltia paralysans nematode. First cases reported in Colombia. Rev Colomb Cienc Pecu 2011; 24(4): 663-669.

Günther MR. Detección de estadios larvarios de nematodos de la familia Angiostrongylidae en moluscos terrestres del sur de Chile [tesis]. Valdivia: Universidad Austral de Chile; 2014.

Helm J, Roberts L, Jefferies R, Shaw SE, Morgan ER. Epidemiological survey of Angiostrongylus vasorum in dogs and slugs around a new endemic focus in Scotland. Vet Rec 2015; 177(2): 46-51. http://dx.doi.org/10.1136/vr.103006. PMid:25934261.

Ibrahim MM. Prevalence and intensity of Angiostrongylus cantonensis in freshwater snails in relation to some ecological and biological factors. Parasite 2007; 14(1): 61-70. http://dx.doi.org/10.1051/parasite/2007141061. PMid:17432058.

Kuzmin Y, Junker K, Bain O. Infective larvae of Rhabdiasidae (Nematoda): comparative morphology of seven European species. Acta Parasitol 2014; 59(1): 31-41. http://dx.doi.org/10.2478/s11686-014-0206-6. PMid:24570048.

Landler L, Nuñez JJ. European invaders in South America: terrestrial snails and slugs in Southern Chile. J Conchol 2012; 41(2): 263-265.

López-Contreras F, Rojas-Barón L, Gómez M, Morera F, Sepúlveda P, Moroni M, et al. Molecular detection of Gurltia paralysans by Semi-Nested PCR in cerebrospinal fluid and serum samples from domestic cats (Felis catus). Animals (Basel) 2020; 10(7): 1169. http://dx.doi.org/10.3390/ani10071169. PMid:32660139.

Martin-Alonso A, Abreu-Yanes E, Feliu C, Mas-Coma S, Bargues MD, Valladares B, et al. Intermediate hosts of Angiostrongylus cantonensis in Tenerife, Spain. PLoS One 2015; 10(3): e0120686. http://dx.doi.org/10.1371/journal.pone.0120686. PMid:25803658.

Morley NJ. Aquatic mollusc as auxiliary host for terrestrial nematode parasites: implications for pathogen transmission in a changing climate. Parasitology 2010; 137(7): 1041-1056. http://dx.doi.org/10.1017/S0031182010000016. PMid:20388234. 
Moroni M, Muñoz P, Gómez M, Mieres M, Rojas M, Lillo C, et al. Gurltia paralysans (Wolffhügel, 1933): description of adults and additional case reports of neurological diseases in three domestic cats from southern Chile. Vet Parasitol 2012; 184(2-4): 377380. http://dx.doi.org/10.1016/j.vetpar.2011.08.035. PMid:21944845.

Peña G. Hallazgos clínicos, hematológicos, bioquímicos y de lavado broncoalveolar en 8 gatos domésticos (Felis catus) con paraparesis/ plejia producida por Gurltia paralysans [tesis]. Valdivia: Universidad Austral de Chile; 2014.

Rivero R, Matto C, Adrien M, Nan F, Bell T, Gardiner C. Parasite meningomyelitis in cats in Uruguay. Rev Bras Parasitol Vet 2011; 20(3): 259-261. http://dx.doi.org/10.1590/S1984-29612011000300017. PMid:21961761.

South A. Terrestrial slugs biology, ecology and control. London: Chapman \& Hall; 1992. http://dx.doi.org/10.1007/978-94-011-2380-8.

Teixeira CG, Thiengo SC, Thome JW, Medeiros AB, Camillo-Coura L, Agostini AA. On the diversity of mollusc intermediate hosts of Angiostrongylus costaricensis Morera \& Cespedes, 1971 in Southern Brazil. Mem Inst Oswaldo Cruz 1993; 88(3): 487-489. http:// dx.doi.org/10.1590/S0074-02761993000300020. PMid:8107609.

Togni M, Panziera W, Souza TM, Oliveira JC Fo, Mazzanti A, Barros CSL, et al. Aspectos epidemiológicos, clínicos e anatomopatológicos da infecção por Gurltia paralysans em gatos. Pesq Vet Bras 2013; 33(3): 363-371. http://dx.doi.org/10.1590/ S0100-736X2013000300015.

Valdovinos C, Olmos V, Moya C. Moluscos terrestres y dulceacuícolas de la Cordillera de la Costa chilena. In: Smith-Ramírez C, Armesto JJ, Valdovinos C, editors. Historia, biodiversidad y ecología de los bosques costeros de Chile. Santiago: Editorial Universitaria; 2005. p. 292-306. 